\title{
The Cost of Holding Foreign Exchange Reserves
}

\author{
Eduardo Levy Yeyati and \\ Juan Francisco Gómez
}

CID Faculty Working Paper No. 353

May 2019

C Copyright 2019 Levy Yeyati, Eduardo; Gómez, Juan Francisco; and the President and Fellows of Harvard College

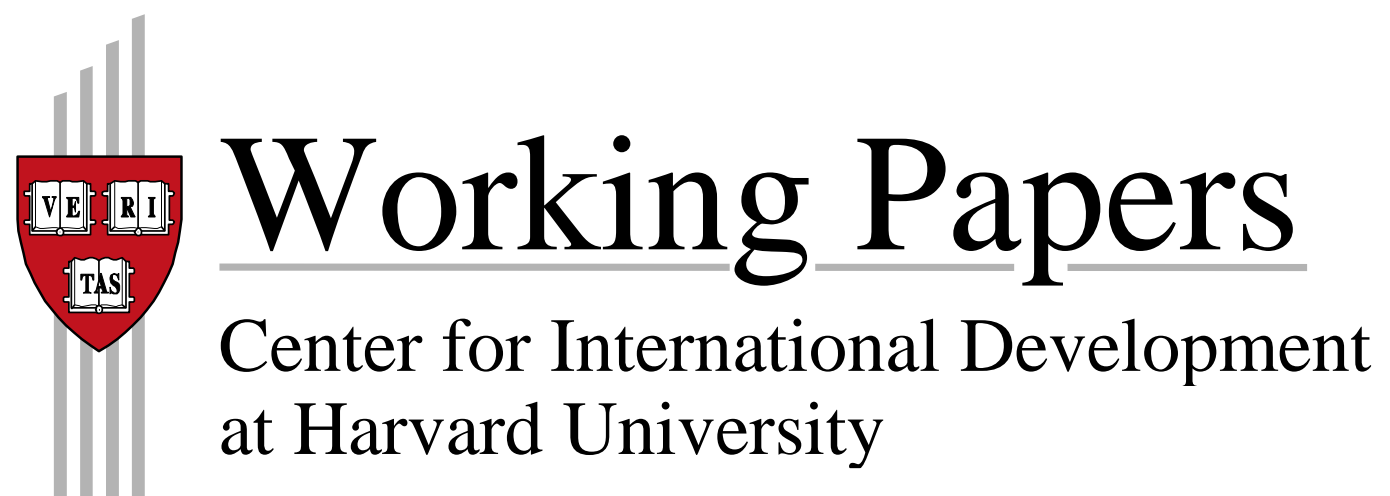




\title{
The cost of holding foreign exchange reserves
}

\author{
Eduardo Levy Yeyati \\ Juan Francisco Gómez ${ }^{1}$
}

\begin{abstract}
Recent studies that have emphasized the costs of accumulating reserves for self-insurance purposes have overlooked two potentially important side-effects. First, the impact of the resulting lower spreads on the service costs of the stock of sovereign debt, which could substantially reduce the marginal cost of holding reserves. Second, when reserve accumulation reflects countercyclical LAW central bank interventions, the actual cost of reserves should be measured as the sum of valuation effects due to exchange rate changes and the local-toforeign currency exchange rate differential (the inverse of a carry trade profit and loss total return flow), which yields a cost that is typically smaller than the one arising from traditional estimates based on the sovereign credit risk spreads. We document those effect s empirically to illustrate that the cost of holding reserves may have been considerably smaller than usually assumed in both the academic literature and the policy debate.
\end{abstract}

Keywords: International reserves, exchange rate policy, capital flows, financial crisis

JEL classifications: E42, E52, F33, F41

\footnotetext{
${ }^{1}$ Eduardo Levy Yeyati is with the School of Government at Universidad Torcuato Di Tella; email address: ely@utdt.edu. Juan Francisco Gómez is with the Department of Economics at Universidad de Buenos Aires. The usual disclaimers apply.
} 


\section{The case for and against reserve accumulation}

The accumulation of international reserves is not new, but became a topical subject -and an area of academic and policy research- in the 2000s, due to two unrelated phenomena: the Chinese effort to counter the appreciation of its exchange rate as a results of its growing trade surplus, and the build up of a precautionary stock of reserves, primarily in South East Asia, after the currency crises of the late 90s. This pattern of reserve accumulation and hoarding, however, has not been exclusive of Asian countries, as leaning-against-the-wind (LAW) exchange rate intervention has been common in most emerging economies, particularly in financially open commodity exporters where reserves reflected the ups and downs of the twin commodity and financial cycles.

As a result, the active policy of hoarding a substantial stock of international reserves has been attributed to three main motives:

1. A commercial or 'neo mercantilist' motive to keep the currency undervalued to promote faster growth.

2. A self-insurance or 'precautionary' motive to create a dollar liquidity buffer to cope with - and ultimately discourage- self-fulfilling liquidity runs in economies with substantial dollar liabilities.

3. An exchange rate-smoothing or 'leaning against the wind' motive to prevent cyclical real exchange rate fluctuation, which in turn may be related to a mercantilist objective (to prevent temporary losses of competitiveness) or precautionary objectives (to avoid temporary overvaluations that may introduce downside exchange rate risks and excessive volatility). ${ }^{2}$

A number of papers (Prasad et al., 2006; Levy Yeyati and Sturzenegger, 2007; Rodrik, 2008) examined the mercantilist motive. From another point of view, Jeanne and Ranciere (2006) remark that there are others who point out that reserves buildup may be related more to an unintended consequence of policies oriented to achieve and maintain large current account surpluses. ${ }^{3}$ That said, the literature on international reserves have centered primarily on motives 2 and 3 . While in the early 2000s it tended to focus on the precautionary motive, the evidence from most economies -and recent empirical tests- have been increasingly pointing to exchange rate smoothing as the main driver of the stock of reserves. More precisely, whereas earlier work has highlighted that reserves are positively correlated with past balance of payments crises (Aizenman and Lee, 2005) and with the degree of financial dollarization

\footnotetext{
${ }^{2}$ Indeed, one could see leaning-against-the-appreciation-wind during expansions as the countercyclical prudential response to procyclical capital flows and real exchange rates, the goal of which is to avoid current-account deficits in good years and prevent a dollar squeeze in the downturn. Such a strategy would be related to precautionary motives, although it would differ from the simple hoarding of liquid assets typically associated with the precautionary story.

${ }^{3}$ A typical figure here is a country that maintain a constant current account surplus with a tradable sector net bidder of local currency, who sells its foreign currency net export proceeds to the central bank in order to not restring its domestic absorption. By this token, the consolidate government can accumulate reserves without the necessity of incurring in new borrowing.
} 
(Levy Yeyati, 2006b), latest additions to the literature have focused on the link between overvaluation and development and the costs and consequences of LAW interventions.

The arguments against reserve accumulation by emerging economies have been often predicated based on three premises:

- $\quad$ reserves introduce negative externalities: they perpetuate global imbalances and depress interest rates, stimulating asset bubbles,

- $\quad$ precautionary reserves are not efficient: inasmuch as they are purchased to build a liquidity war chest to prevent or cushion sudden capital flow reversals, they can be optimally substituted by centralized financial safety nets; and

- $\quad$ reserves are costly: to the extent that precautionary reserves are purchased with dollar debt, reserve holders pay a carrying cost roughly proportional to the sum of their sovereign credit risk premium and (because reserves are typically held in short-term instruments) the term premium in the reserve currency of choice.

Of these three criticisms, the first one reflects a complex coordination problem that exceeds cost-efficiency considerations by individual countries, and the second one ignores the practical limits of a fully functioning international lender of last resort or the correlation risk of portfolio flows in the event of a systemic shock ${ }^{4}$.

But it is the third aspect of the debate on reserve policy that is the subject of this paper. More specifically, the article will discuss the costs of hoarding reserves and will argue that the correct way of computing these costs depends crucially on the underlying motives. In the case of selfinsurance, the marginal cost of carrying reserves is proportional to the marginal cost of the debt that implicitly funds (alternatively, that could be cancelled with) reserves, net of the returns obtained on reserves - which typically amounts to the sovereign spread over the riskfree rate plus the term premium if there is a duration mismatch between reserves and debt. If the purchase of reserves is aimed at countering exchange rate variations, reserves are funded essentially by issuing issuing local currency-denominated debt, ${ }^{5}$ which pays the local-to-foreign currency interest rate differential (a quasi fiscal cost) and incurs valuation losses due to changes in the nominal exchange rate (in other words, takes the other side of a "carry trade"). As we document empirically, the cost of reserves in this two cases differs substantially.

Our route map is as follows. In the following section, we explore in more detail the pros and cons of hoarding international reserves according to their motives, and argue that the costs may have been overstated. In Section 3 we us a simple model of the determination of the sovereign risk spreads to show how the traditional measure of the cost of precautionary reserves should be corrected to account for the impact of reserves on spreads. Section 4 estimates empirically the cost of reserves in the LAW case, and show how this costs depends essentially on the interest rate differential: for countries with modest differentials, the cost of exchange rate intervention through the purchase of reserves may be minimal (or there may even be a small profit). Section 5 summarizes the main findings.

\footnotetext{
${ }^{4}$ On the high cross-country correlation of reserve needs displayed during episode of global distress, see Cordella and Levy Yeyati (2010).

${ }^{5}$ Since intervention is geared to offset the demand for the local currency, the issuance dollar debt would not do the trick in this case.
} 


\section{Motives and costs}

The unrest as a result of the currency crises of the late 1990s -a combination of a global financial downcycle and self-fulfilling liquidity runs-coupled with the reluctance of developing economies to put themselves in the hands led emerging economies to embrace a debt dedollarization and self-protection strategy through, respectively, the development of domestic financial markets and the buildup cushion of liquid international reserves ${ }^{6}$.

This approach reflected the view expressed by many observes about the sources of financial stress in the emerging world by the end of the century. As Martin Feldstein puts it regarding the stream of crises en South East Asia: "Liquidity is the key to self-protection. A country that has substantial international liquidity large foreign exchange reserves and a ready source of foreign currency loans -- is less likely to be the object of a currency attack" (Feldstein, 1999).

This view was only confirmed in the Great Recession that followed the failure of Lehman Brothers in September 2008, as many governments and central banks, including in the developed world, rushed to obtain greater 'liquidity assurance', that is, the assurance of having access to international liquidity in any future crisis (Moessner and Allen, 2010) -including, most notably, through bilateral currency swap arrangements with the U.S. Federal Reserve.

Figure 1 panel A, which describes the composition of global international reserves from the last thirty years, shows the massive increase in emerging economies' share in the global distribution, peaking at $68 \%$ in the aftermath of the global crisis. Figure 1Panel B shows an important increase in reserves after the failure of Lehman Brothers, especially in China (reaching a peak of more than 3 times of increase in 2014). Ten years after that traumatic episode, emerging countries as a group almost have doubled (1.9 times) its international reserves, and, as a puzzle, that figure is less than the buildup registered in the advanced countries (2.5 times). Interestingly for pour purposes is that fact that, since the mid 90s, the evolution of global international reserve stocks are largely explained by a few countries (China, Japan, Taiwan and oil exporters accounts for a ten-year-average of 56\% of world reserves), which did not suffer currency crises nor faced a shortage of hard-currency liquidity: To what extent, then, is reserve accumulation driven by liquidity insurance?

\footnotetext{
${ }^{6}$ See, Fernandez-Arias and Levy-Yeyati (2010)
} 
Figure 1: Evolution and composition of international reserves

Panel A

Distribution of international reserves...

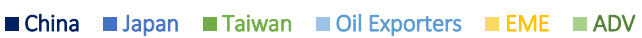

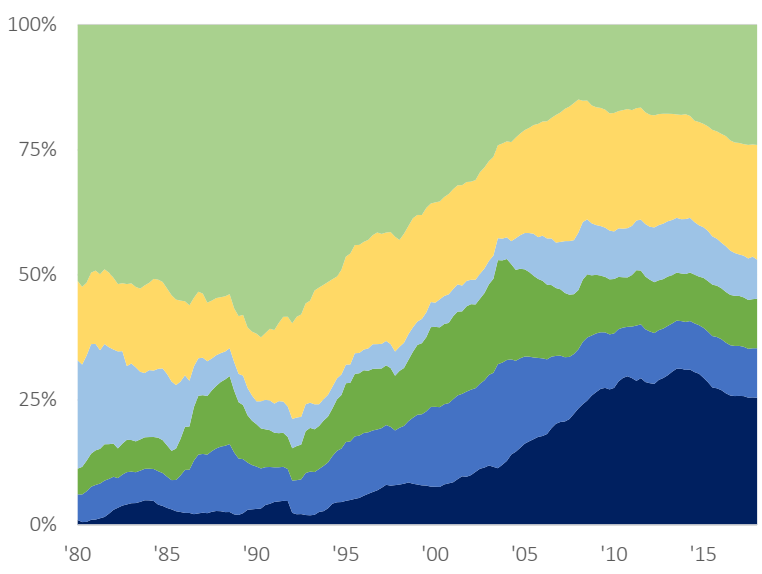

Panel B

... and its increase after Lehman's Failure $(20071 \mathrm{Q}=1)$

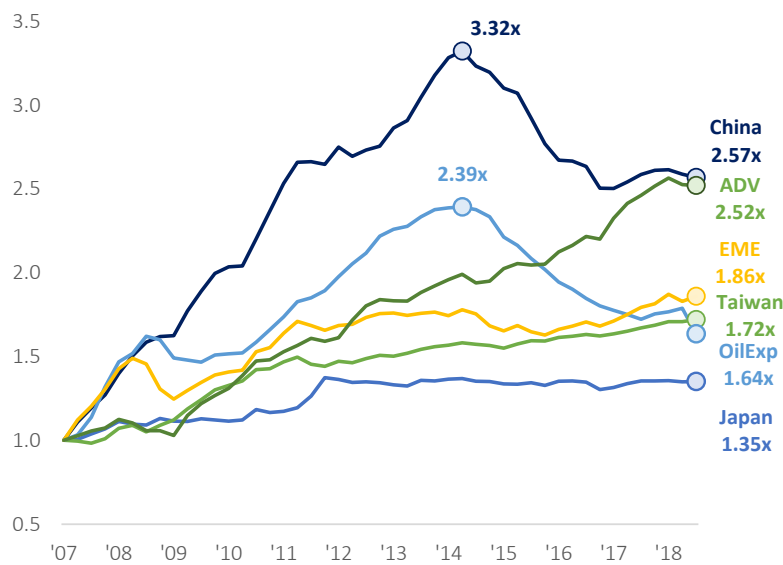

Source: IMF' International Finantial Statistics and authors calculations. ADV stands forAdvanced Economies (IMF, code XR29) excluding Japan, EME stands for Emerging and Developoing Countries (IMF code XR43) excluding China, Taiwan and Oil Exporters (Algeria, Iran, Iraq, Kuwait, Libya, Nigeria, Oman, Qatar, Saudi Arabia, United Arab Emirates, Venezuela).

The precautionary motive for reserves evolved as the depth and nature of financial globalization developed in the 2000s. As Rodrik (2006) recall, prior to financial globalization, the main driver of hoarding reserves became from the current account side of the balance of payments, and the Central Banks used to follow a rule of thumb of holding a quantity of foreign exchange reserves equivalent to three months of imports (see Figure 2): reserves were treasured as an insurance against current account reversals. In the 1990s, the hoarding of reserves accelerated, and the stock started to be measured against financial magnitudes, more specifically, flows in the financial account of the balance of payments: reserves works as an insurance against sudden stops in capital markets.

Figure 2: Total Reserves in month of imports

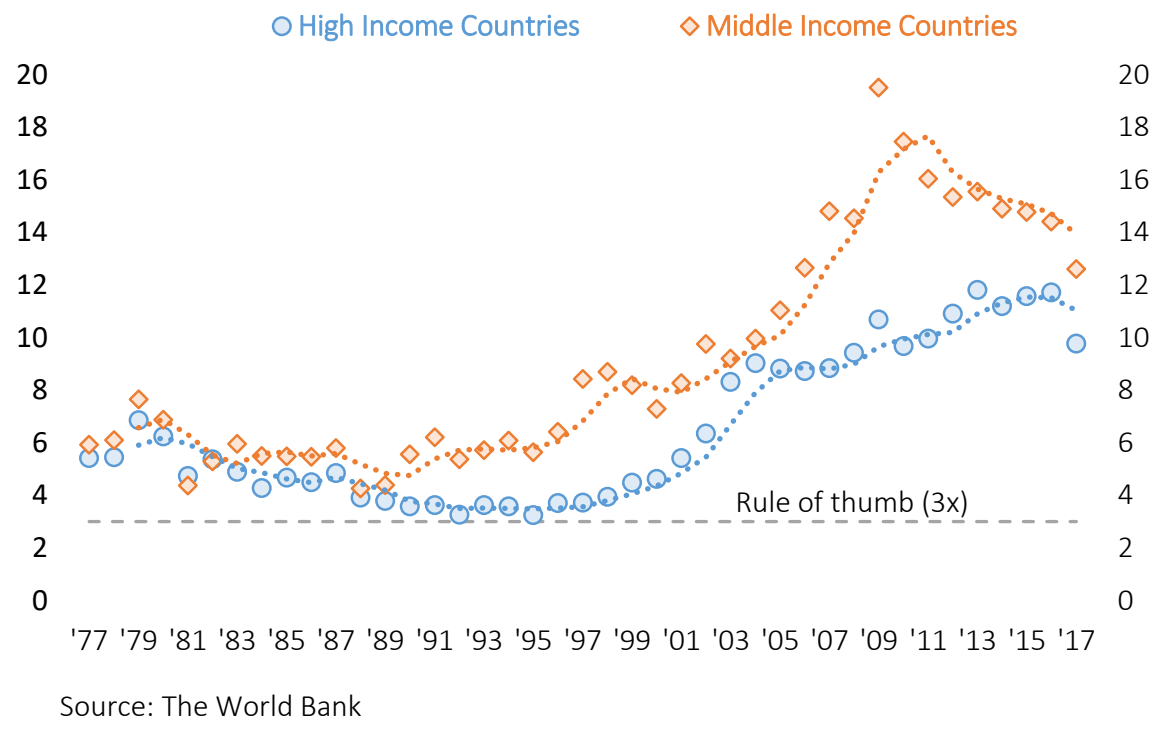

It was with this in mind that the 1991 "Guidotti-Greenspan rule!" was postulated to hold liquid reserves equal to the country's foreign currency liabilities due within a year, a criterion that was at the time formally embraced for policy guidance by the IMF. In a more recent 
contribution, Obstfeld et al (2010) argued that reserve adequacy should be judged relative to the broad monetary aggregate, $M 2$, a proxy for financial development, due to its good tracking of the potential pressure on reserves resulting from a fight out of domestic-currency bank deposits. The intuition is simple: in the event of a run, it is not the transactional monetary base but savings (quasi moneys) that go to the foreign currency for protection.

\subsection{Are reserves suboptimal?}

The literature on the 'optimal level' of reserves is often rationalized in terms of their insurance value against balance of payments crisis, relative to their cost, which is typically assumed to be proportional to the credit risk spread of the country (a point to which we come back below). ${ }^{7}$

Following Moessner and Allen (2010), satisfactory techniques for providing liquidity assurance should: (i) reassure that the international liquidity needs will be met, (ii) avoid excessive moral hazard, and iii) avoid placing an unreasonable burden on liquidity providers. Three types of arrangements fit these criteria: a multilateral pool of liquidity, bilateral arrangements, and unilateral actions. A priori, it is known that self-insurance is more costly and less efficient than a pool of savings that benefit from risk diversification. For the same reason, the centralized holdings of precautionary reserves by an international agency, has two potential advantages:

I. It requires a smaller stock than individual self-protection for a given risk exposiure; and

II. It is less costly, to the extent that the pool might benefit from peer control and face a lower credit risk premium than individual countries (as is the case for many real life reserve pools and regional multilateral credit institutions). ${ }^{8}$

In a broader sense, multilateral agreements additionally reduce de 'psychological' negative effect of having to use own reserves: whereas reserves help dissuade ex ante a foreign exchange run, their use (indeed, the sight of rapidly falling reserves) may be seen by market agents as a signal that confirms the initial fears that triggered the run in the first place, reducing their its ex-post effectiveness. International loans are less prone to this undesired effect.

Examples of reserve pools include the Chiang Mai Initiative (CMI) in East Asia, the Latin American Reserve Fund (LARF), the European Stability Mechanism (ESM) and, of course, the IMF $^{9}$. However, the increase in the correlation risk in the event of a systemic event (namely, the fact that all insured countries are likely to draw liquidity at the same time) should largely erode the diversification gains. At the same time, moral hazard considerations, coupled with political constraints, have led some of this reserve arrangements (CMI, EBRD) to fall back on some version of the IMF conditionality as a pre-condition for full access. Ultimately, only the issuer of a reserve currency favored by the flight to quality in the event of a global liquidity crunch could retain the systemic liquidity risk without a hefty carrying cost. Thus, the

\footnotetext{
${ }^{7}$ Readers interested in this models might look at Jeanne \& Ranciere (2011), Jeanne \& Sandri (2016) and references therein.

8 See, for example, FLAR (2015).

9 Fernandez Arias and Levy Yeyati (2010) explore the relationship between a reaction to the traditional IMF approach and the emerging in the 2000s of regional safety nets (CMI and LARF) as alternatives. It is also worth noting that emerging members of the $\mathrm{G} 20$ are main promotors of global financial safety nets, having achieved reforms aimed at enhancing financial resources and renewing instruments for emergency liquidity provision, but failed at accomplish reforms concerning the governing structure of International Financial Institutions. For a review, see Cheng (2016).
} 
diversification argument against self-insurance is considerably weakened: only these 'issuers of last resort' (the Fed, the Bank of Japan, to a lesser extent the ECB) or big-pocket lenders such as China, could provide liquidity in a systemic event, and they would typically do that under conditions that often deters the preventive use of the facility-leaving the country best served by its own reserves.

\subsection{Are reserves precautionary?}

Official exchange rate intervention in the foreign exchange market has been the subject of a vast academic and policy-related literature ${ }^{10}$. Its link with the accumulation of international reserves is usually established through the goal of keeping the exchange rate undervalued for mercantilist reasons. However, there is plenty of evidence indicating that intervention is primarily geared to limiting what policymakers may see as unwarranted (and possibly harmful) deviations from equilibrium levels ${ }^{11}$.

At the same time, in most cases, this countercyclical exchange rate stabilization policy appears to account for reserve accumulation better than the precautionary motive. A simple regression of the change in the reserve-to-GDP ratio on these the two motives (proxied, respectively, by the M2-to-GDP ratio, and by the financial account balance over GDP) points in the same direction (see Levy Yeyati and Sturzenegger 2010b for details).

As a final note, exchange rate smoothing does not require that reserves be held in short, lowyielding liquid assets. Even precautionary reserves - unlikely to be used in full - can afford to be partially invested in higher yielding long-run saving instruments as in the case of sovereign wealth funds: the bias towards short-run assets seems to reflect more the objective to minimize short run valuation changes than to maximize liquidity; in other word, it may be the solution to an agency (the reserve manager) rather than a financial problem. ${ }^{12}$

\subsection{Are reserves costly?}

In the self-insurance story, part of the proceeds of capital inflows in good times are purchased and saved by the central bank for the rainy days. To the extent that part of these inflows are associated with past or current sovereign hard-currency debt issuance, one could think of the opportunity cost of reserves as the cost of serving such debt; after all, by consolidating the government and the central bank into one balance sheet, the relevant leverage concept should be net debt, namely, sovereign debt minus reserves. Indeed, to the extent that reserves could be swapped in exchange for debt, the cost of reserves should be proportional to the interest rate differential between the two. Hence, the use of the sovereign premium (the difference between the yield on the sovereign debt and the risk-free returns on international reserves) as a proxy for the cost of reserves. Because reserves are held in short rate risk-free assets, this

\footnotetext{
10 Sarno and Taylor (2001) provide an early survey for advanced countries, and Levy Yeyati and Sturzenegger (2010) provide a review with a focus on developing economies.

${ }^{11}$ See, among others, BIS 2005, BIS 2013, Levy Yeyati (2010), Adler and Tovar (2011) and Daude et. al. (2014).

12 Perhaps in the realization of this inconsistency between goals (precautionary exchange rate smoothing) and instruments (short-run reserve assets) lies the hope to reduce the excessive demand for the latter that triggered the quest against reserve accumulation in the first place.
} 
gap is, in turn, a function of the sovereign risk spread plus the hard-currency interest rate premium (see, Jeanne and Ranciere, 2011, and Rodrik, 2006).

However, the cost of reserves tends to differ from this simple formula for at least two reasons:

- First, to the extent that the availability of liquid reserves affects credit risk (and the interest rate) paid on the total (public and private) debt stock, the marginal cost of carrying reserves for indebted economies may be significantly lower than the sovereign spread. If, for a given net debt stock, a larger stock of liquid foreign currency assets tightens the sovereign spread, the resulting fiscal gain in rollover costs should be net out from the spread (Levy Yeyati 2008a) -the gains would be larger for the country as a whole (and, indirectly, for the Treasury) if we take into account the rollover costs on private debt. We elaborate on this argument in Section 2.

- Second, and more important, if reserve purchases follow a LAW pattern, the central bank would sustain important valuation losses only to the extent that appreciation pressures are permanent. By contrast, if they are due, for example, to cyclical inflows or short-lived term of trade shocks, the reversion of the exchange rate to its earlier, more depreciated level would eliminate much of the valuation losses, and, in some cases, may even result in central bank profits. Section 3 explores this second argument more in detail.

\section{Self-insurance and the marginal cost of reserves ${ }^{13}$}

When a central bank is embraced in a self-insurance reserve accumulation policy, the acquisition of the foreign currency is fulfilled by borrowing abroad ${ }^{14}$. The debt may be issued by a private firm and come in the form of capital inflows purchased by the central bank or directly by the Treasury. In either case, the result is the same: the economy as a whole borrows abroad and invests the proceeds in international reserve assets.

The maturity of both debt and reserves are critical to a complete assessment of the cost of reserves: for instance, Rodrik (2006) assumes that the central bank invest the foreign currency in U.S. Treasuries and that the private firm borrows at short maturities, so that there is no 'maturity mismatch'. From this perspective, the appropriate cost of reserves is approximately equal to the spread between the cost of the borrowing abroad and the yield that the central bank earns on its reserves. For the latter term, the yield on the U.S. Treasury securities is a good proxy; for the former, the private debt often takes place in the commercial bank sector where rates are often priced at the sovereign yield plus a spread. The computation is more straightforward if the borrower is the central government, since in this case the opportunity cost or reserves would be the yield differential between the country and the U.S., that is, the sovereign credit risk spread, for which there is reliable high frequency data.

For this reason, the cost of reserves has been often estimated as the sovereign risk spread plus the hard-currency interest rate term premium (to account for the fact that sovereign

\footnotetext{
13 The section is based on Levy Yeyati (2011).

${ }^{14}$ As stated before, we do not consider the case of hoarding reserves due to current account surplus.
} 
borrowing often has a longer duration than reserves $)^{15}$ : if a country issued debt with an average 5-year duration (close to the average duration of JP Morgan's EMBI) to purchase 2-year U.S. Treasury bills, the cost could be proxied by the sum of the EMBI spread and the difference between the 5-year and the 2-year Treasury yields. Depending on the country's perceived credit risk, the level of global risk aversion and the slope of the risk-free yield curve, this cost could be substantive and may justify alternative forms of liquidity insurance.

There is, however, an additional term that should be taken into account when computing the fiscal cost of self-insurance: the impact of liquid reserves on the sovereign risk and, through this channel, on the debt service. Since the sovereign risk premium reflects the probability of default often linked to dollar liquidity shortages, an increase in liquid reserves, by reducing the probability of a liquidity crisis, it reduces also the spread paid on the full stock of sovereign debt, adding to the marginal benefits of reserve accumulation.

Assume for simplicity that the U.S. Treasury yield curve is flat, so that there is no term premium (alternatively, assume that both reserves and debt are issued with the same one-period maturity), that reserves are fully funded by new hard-currency debt (so that one unit of reserves entails one additional unit of debt: $D=D o+R$, where $R$ is the stock of reserves and Do stands for the debt stock at the beginning of the period), and denoting the sovereign risk premium as $\rho(R, D)$, we can express the government's fiscal cost of holding reserves as:

$$
L(R, D)=\left[r^{f}+\rho(R, D)\right] D-r^{f} \cdot R
$$

from which, recalling that $\frac{\partial D}{\partial R}=1$, the marginal cost of reserves is given by:

$$
\begin{gathered}
\frac{\partial L(R, D)}{\partial R}=\left[\rho_{R}(R, D)+\rho_{D}(R, D)\right] D+\rho(R, D)<\rho(R, D) \\
\Leftrightarrow\left[\rho_{R}(R, D)+\rho_{D}(R, D)\right]<0
\end{gathered}
$$

This tells us that, to the extent that an increase in the reserve buffer more than compensates the negative impact of the corresponding increase in the stock of debt on the credit risk premium (that is, $\left[\rho_{R}(R, D)+\rho_{D}(R, D)\right]<0$ ), then the marginal cost of reserves is less than the sovereign spread usually used as a proxy.

Is this the case in practice? To illustrate the idea numerically, we augment González Rozada and Levy Yeyati's (2005) model of emerging market spreads as a function of exogenous global factors (the international risk-free rate and the global risk aversion) by adding the stock of reserves and sovereign external debt with the private sector (lagged to reduce potential endogeneity concerns), as well as the credit rating (to control for other country-specific, timevarying characteristics). ${ }^{16}$ In addition, either because private debts could be seen as implicitly guaranteed by the government or because private demand of foreign currency to repay those

\footnotetext{
15 See, i.a., Jeanne and Ranciere (2006).

${ }^{16}$ All variables are in logs. All regressions controls are based on monthly data, include country fixed effects and exclude observations for countries in default, for which the spread can no longer be interpreted as a measure of credit risk. Regressions also exclude cases in financial distress (spreads above 1000 basis points) and the crisis years 2008 and 2009, as they are likely to exhibit a qualitatively different relation between reserves and credit risk. We used splines interpolation to turn debt and GDP (originally yearly data) into monthly data.
} 
debts adds to the exchange rate pressure and the risk of a sovereign credit event, we control separately for private foreign currency debt. Table 1 shows the relevant summary statistics, Table 2 the countries and periods covered, and Table A1 the variable definitions and sources.

Estimation results for the full sample are reported in Table. The first regression replicates the original model of global factors (risk aversion, credit rating and international rate), and we include reserves and both sovereign and private debt as ratios over GDP. In the second regression we control for consistency by dropping private debt ratio. The semielasticity with respect to the reserve ratio, $\rho_{R}$, is stable at roughly 1.7 , meaning that, ceteris paribus, a unit increase in the reserve ratio leads to a $1.7 \%$ decline in spreads, while the same with respect to the sovereign debt ratio, $\beta_{D}$, is significantly lower at about 0.7 .

Naturally, part of the benign effect of growing a liquidity buffer is captured by ratings, which usually include measures of reserves stocks in their calculations. Because of that, we estimate the direct impact of reserves on ratings in column 4: as can be seen, reserves ratio improve credit ratings more than the concomitant increase in debt ratios worsens them. It follows that the estimated total (direct plus indirect) effect of reserves on spreads without controlling for ratings (column 3), measured by the difference between the coefficients of reserves and debt, is even larger before. To isolate the results from the effect of the Great Recession of 20082009, we perform the same regressions for two subsamples, one for the period before the crisis and the other after it. Both are reported in Table 4 and Table 5. While the results are comparable, the differential effects of reserves relative to debt narrows in the latest period. ${ }^{17}$

In sum, in the case in which the cost of hoarding reserves, under the assumption that each dollar of reserves is ultimately funded with government debt, is estimated as its sovereign spread, the standard proxy often overstates the cost, as it ignores the benign effect of liquid reserves on spreads. To the extent that liquid reserves reduce credit risk (and the interest rate) paid on the total (public and private) debt stock, the marginal cost of carrying reserves for indebted economies may be lower than the sovereign spread -even more so if we take into account the gains from lower spreads on private debt as well. ${ }^{18}$

\section{Leaning-against-the-wind and the cost of reserves}

In recent years, reserve accumulation has been motivated not exclusively (and probably not primarily) by the self-insurance motive, but rather by a LAW exchange rate policy aimed at containing what the central bank may perceive as excess market volatility in foreign exchange markets. ${ }^{19}$ While it is beyond the scope of this paper to assess when and to what extent one

\footnotetext{
${ }^{17}$ Additionally, we find that the international rate (proxy for international liquidity) performs as expected before the crisis, but as the interest rates reach the so called zero lower bound in the aftermath, the elasticity become negative, meaning that low level of rates in advanced countries started to increase the cost of borrowing for emerging markets.

${ }^{18}$ We could also add that, since the fact that reserves are held in short-dated instruments is related less to liquidity than to central banks' agency problem associated with reserve management practices (for example, the manager's fear of short-term mark-to-market losses), the term premium is in most cases an unnecessary cost.

${ }^{19}$ See Levy Yeyati and Sturzenegger (2010) for a discussion.
} 
motive dominates the other, the distinction between self-insurance and leaning against the wind is essential to the cost analysis.

LAW intervention can be conducted in an unsterilized form, simply by purchasing or selling reserves against the local currency, with the corresponding change in base money, or by sterilizing changes in base money through the sale or purchase of local currency paper. Since the latter is monetary neutral, it is the mechanism preferred by banks concerned with inflation, and has been the most frequent case in recent years.

Faced with appreciation pressures, a LAW central bank accumulates foreign-currency reserves against local-currency debt (more generally, an increase in its local-currency net liabilities), thereby increasing (reducing) its net foreign currency (local currency) position. Note that, in essence, this mirrors the position of a carry trader that short the foreign currency betting on further appreciation: in the absence of transaction costs (including Tobin-type taxes on crossborder flows), the loss of the central bank should equal the profit of the carry trader.

As noted, the main concern about sterilized intervention has been the cost of carry, namely, the frequently large local-foreign currency interest rate differential that the bank has to pay on its local currency-funded reserve position. In effect, this situation might lead central banks to deal with quasi fiscal losses associated to steep interest rate differentials. These differentials may reflect either a decline international rates (for example, due to the spillovers of the U.S. expansionary monetary policy, as highlighted in the financial cycle literature), or a tightening of domestic monetary policy that triggers speculative capital inflows (which the exchange rate intervention tries to offset).

However, the conventional wisdom that associated intervention costs with interest rate differentials ignores another critical aspect of the process of hoarding reserves: the countercyclical nature of LAW intervention and the cyclical valuation effect that works in its favor. If official intervention in the foreign exchange market delays appreciation, the central bank purchases reserves at a relatively low price level, and when the exchange rate finally moves back towards its more depreciated equilibrium, it gives the bank a positive valuation gain. ${ }^{20}$

This has a trivial but often overlooked implications: the cost of LAW reserve accumulation must be measured over the long run (to include the full cycle). More specifically, in floating exchange rates regimes, participation of central banks in the foreign exchange markets is expected to have at times positive and negative valuation effects. It follows that LAW reserve accumulation would sustain important valuation losses only to the extent that the appreciation pressures are permanent, in which case the intervention would be closer to the mercantilist motive that aims at gaining price competitiveness by preserving an undervalued currency. By contrast, if they are due to cyclical speculative inflows due to a differential monetary policy stance, or to shortlived terms of trade shocks, the reversion of the exchange rate to its earlier, more depreciated level would eliminate much of the valuation losses, and may even be greater than the carry

\footnotetext{
20 While not strictly related to the focus of this paper, the same is true for the opposite case of a temporary depreciation pressure: the bank sells at a depreciated exchange rate reserves that were purchased or are later replenished at a lower parity.
} 
effect (i.e., a net profit scenario), since it benefits from the fact that the bank purchase reserves when they are cheap and sells them when they are expensive in term of the local currency.

If the uncovered interest rate parity (UIP) condition holds, the interest rate differential should equal the expected exchange rate variation (if the differential favors the local currency, the latter should depreciate, and vice versa) so that the cost of sterilized purchases should ultimately be, on average, similar to purchases directly funded by dollar debt (the only difference being that, in the first case, it is the central bank that bears the currency risk). However, as UIP seldom holds in the short run, the central bank could arbitrate cyclical deviations from UIP. Ultimately, both the amplitude of these deviations and the intensity of interventions critical to assess the fiscal costs of LAW. ${ }^{21}$ At any rate, in the absence of taxes on foreign exchange transactions or other relevant sources of transaction costs, the stream of profits and losses of a sterilized LAW central bank intervention should be the reverse of the one received by a carry trade speculator.

Figure 3 shows back-of-the-envelope empirical estimates of the cumulative valuation and carry cash flows for a few central banks known to have intervened actively in foreign exchange markets (see Levy Yeyati and Sturzenegger 2010 for details). On the other hand, the cost of carry is positive and accumulates steadily over time. On the other, valuation losses accumulate during the appreciation phase and decline during an exchange rate correction (see, for instance, Brazil prior to and after 2012s), and a LAW central bank tends to buy cheap reserves that it sells later on at a higher price in times of currency stress, a 'market maker' gain that partially offsets the cost of carry. As a result, while the total return from intervention tended to be negative for countries with steep interest rate differentials (the so-called "curry currencies" like Brazil or Russia, characterized by liquid foreign exchange markets and wide interest rate differentials often unrelated with exchange rate expectations), many central banks faced modest costs or even minor gains as they benefitted from large valuation gains in risk-off periods such as the global crisis of 2008-2009 or the euro crisis) and reserves were sold at higher parities to contain the currency run.

\footnotetext{
${ }^{21} ¿$ Can the central bank intervene in a way that maximizes valuation gains? While that purpose is not often written in official documents, Sarno and Taylor (2002) suggest that the information available to, and used by market agents is often less accurate that the authorities'. Along the same lines, Blinder et al (2008) argues that 'central banks may have, or may be believe to have, superior information on the economic outlook [because they] usually devote many more resources than private sector forecasters to forecasting and even to estimating the underlying unobservable they state of the economy'. By this token, the central bank with its powerful research department, may use its more accurate data to intervene in a profitable way, by hoarding reserves while its price is perceived to be low, and selling when it is perceived to be high. A similar argument has been proposed and tested to explain why an unanticipated interest rate hike by the central bank typically shifts the yield curve upwards despite the fact whereas it is expected to reduce inflation over the long run (Romer and Romer, 2000).
} 
Figure 3: LAW, Cumulative Profits and Losses (P\&L) from reserve purchases

All figures in billion dollars, unless otherwise noted

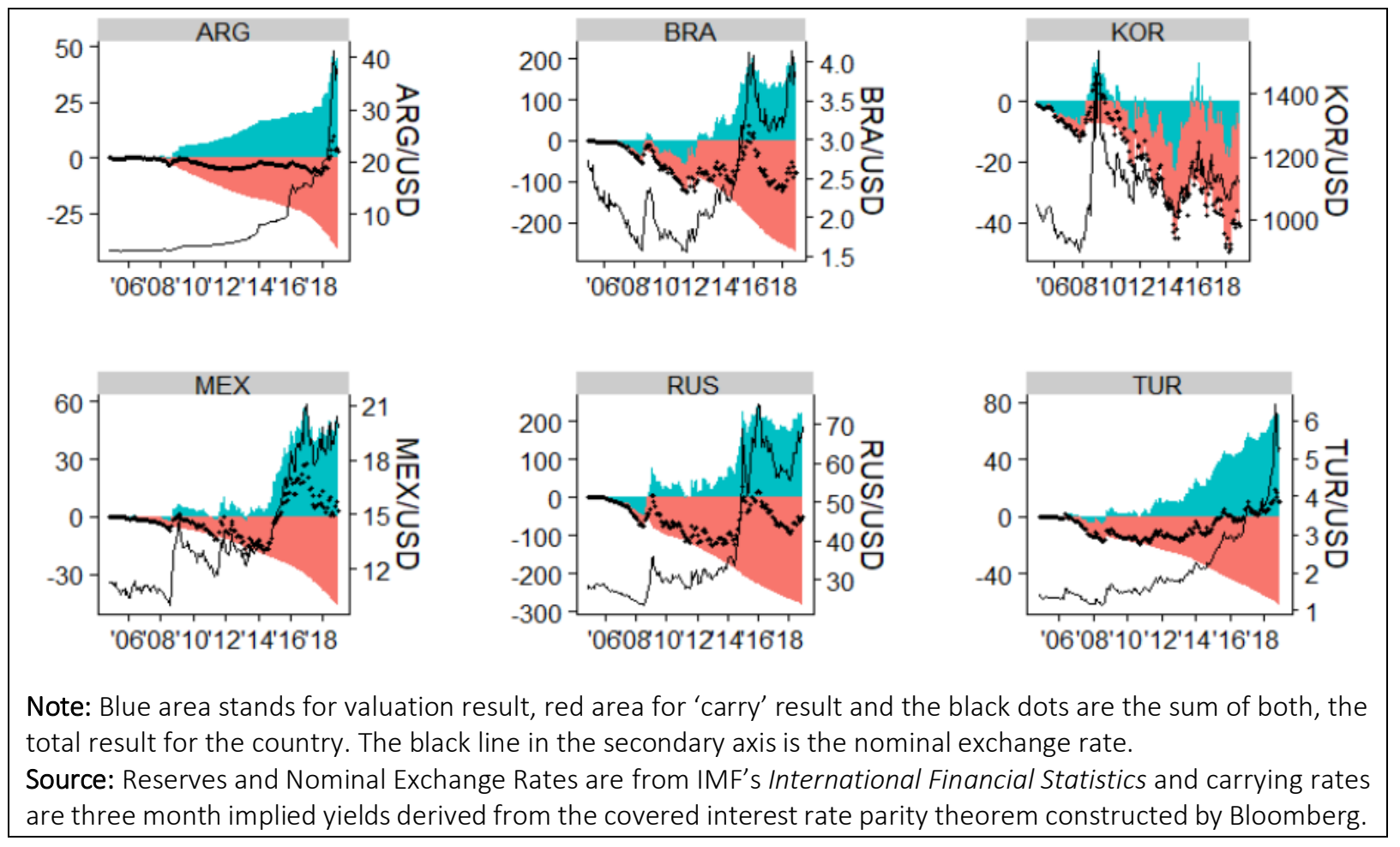

¿How economically important are these costs? In Figure 4, we perform the same analysis, this time computing quasi fiscal intervention results and losses relative to GDP over each fiscal year. Again, "carry currencies" in Brazil and Russia display the largest P\&L figures in the panel, reaching quasi fiscal profit and losses of almost 5 percent of the GDP. In contrast, in normal cases, the incidence of the carry effect looks at first glance less important than the valuation effects, and the total annual cost of holding reserves looks fairly small.

Figure 4: Annual P\&L from reserve purchases as percent of GDP

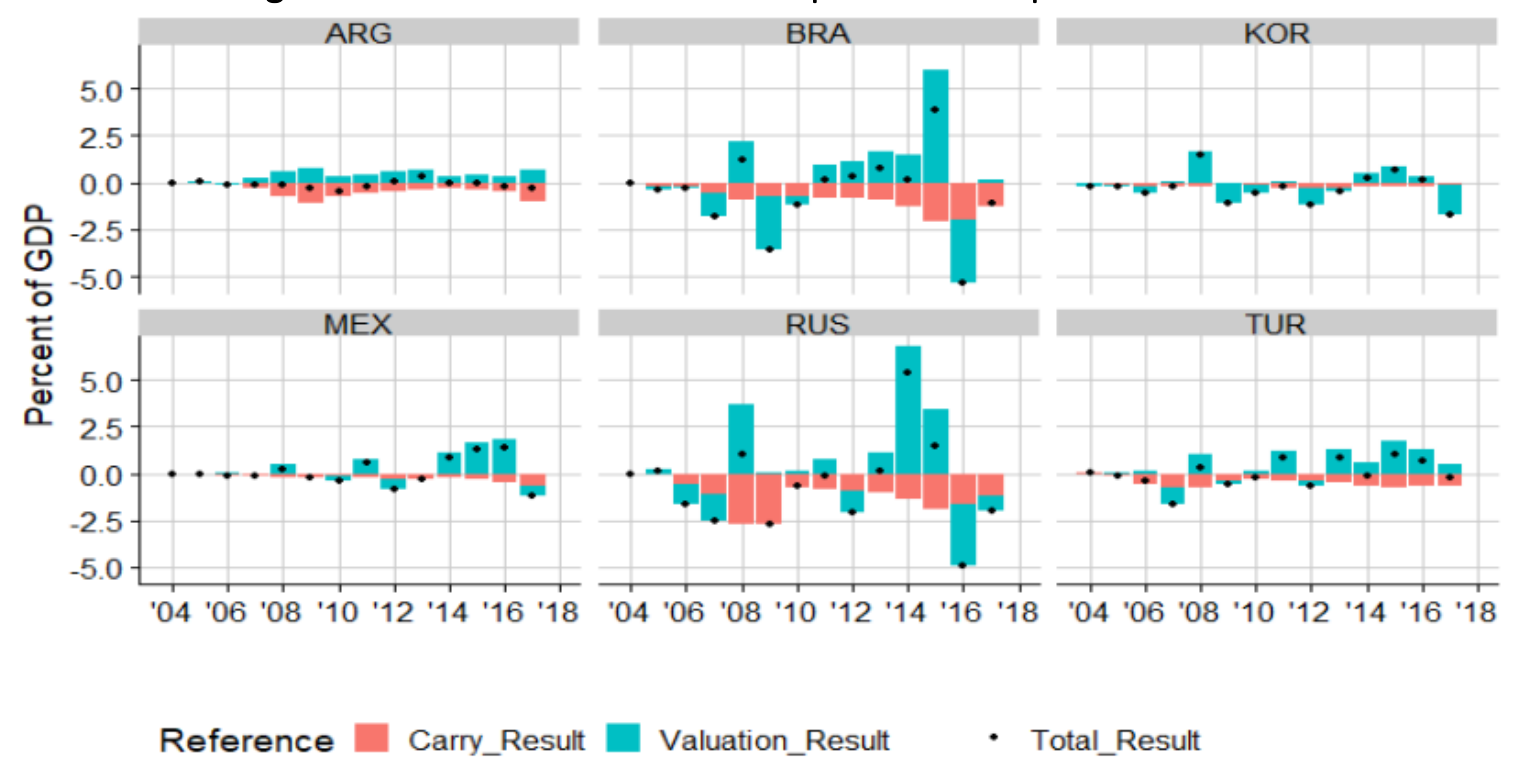

Source: Same as Figure 3, plus GDP from the World Bank. 
If we look at the average of these figures over the period of analysis, countries of the sample exhibit average valuation gains of 0.35 of GDP, and average carrying costs of $0.59 \%$ of GDP for an average total return of $0.24 \%$ of GDP (see Figure 5 ). We can compare this estimates with those arising from the traditional sovereign-spread-plus-term-premium proxy discussed in the previous section (abstracting, for simplicity, from the marginal effect on spreads). As shown in the last column of Figure 5, the traditional measure would overestimate the cost of holding reserves under LAW.

Figure 5: Average Cost of Reserves (2005-2017)

\begin{tabular}{|l|ccc|c|}
\hline \multirow{2}{*}{} & \multicolumn{3}{|c|}{ Leaning Against the Wind } & \multirow{2}{*}{$\begin{array}{c}\text { Self } \\
\text { Insurance (2) }\end{array}$} \\
\cline { 2 - 3 } & Valuation & Carry (1) & Total & \\
\hline Argentina & $0.37 \%$ & $-0.47 \%$ & $-0.10 \%$ & $-0.32 \%$ \\
Brazil & $0.40 \%$ & $-0.90 \%$ & $-0.50 \%$ & $-0.43 \%$ \\
Korea, Republic of & $-0.10 \%$ & $-0.18 \%$ & $-0.28 \%$ & NA \\
Mexico & $0.31 \%$ & $-0.24 \%$ & $0.07 \%$ & $-0.22 \%$ \\
Russian Federation & $0.59 \%$ & $-1.20 \%$ & $-0.61 \%$ & $-0.66 \%$ \\
Turkey & $0.47 \%$ & $-0.49 \%$ & $-0.02 \%$ & $-0.23 \%$ \\
All Countries Average & $0.35 \%$ & $-0.59 \%$ & $-0.24 \%$ & $-0.38 \%$ \\
\hline
\end{tabular}

(1) Proxied by the Covered Interest Parity

(2) Proxied by EMBI + UST Term Premium (5y-Fed Funds)

Source: Same as Figure 4, plus EMBI from The World Bank and the UST Term premium is 5Year Treasury Constant Maturity Minus Federal Funds Rate from the Federal Reserve Bank of St. Louis

In sum, while realized intervention costs depend crucially on the timing and nature of intervention, and tend to vary considerably over the cycle (particularly for LAW interventions), the conventional view that reserves are costly due to wide sovereign spreads or heavy quasi fiscal losses associated with interest rate differentials and permanently misaligned exchange rates appears to have been overstated.

\section{Why do central banks intervene (and at what cost)?}

Recent studies that have emphasized the costs of accumulating reserves for self-insurance purposes have overlooked two potentially important side-effects.

First, the impact of the resulting lower spreads on the service costs of the stock of sovereign debt, which could substantially reduce the marginal cost of holding reserves. It should be noted that the computations in this paper provide a lower bound to these marginal benefits in terms of lower financing costs, as they do not incorporate similar gains for the private sector - where borrowing costs are typically bounded below by those of the sovereign - and the resulting positive impact on fiscal accounts from improved activity and lower, in the presence of implicit guarantees, lower contingent liabilities. While these findings do not deny the fact that selfinsurance is costly and should be considered as a second best solution in a context of imperfect international financial markets, they certainly shed a different light on the cost-benefit that should inform the decision about the optimal amount of reserves. 
Second, in the increasingly common case in which reserve accumulation reflects countercyclical LAW central bank interventions, the actual cost of reserves should be measured as the sum of valuation effects due to exchange rate changes and the local-to-foreign currency exchange rate differential (the inverse of a carry trade profit and loss total return flow), which yields a cost that is typically smaller than the one arising from traditional estimates based on the sovereign credit risk spreads.

Needless to say, these estimates could be refined to take into account country specific characteristics (the currency and maturity composition of sovereign debt, among other things, should certainly influence the impact of liquid reserves). However, they help illustrate the main message of this note, namely, that the cost of holding reserves may have been considerably smaller than usually assumed in both the academic literature and the policy debate. 


\section{References}

Adler, G. and C. E. Tovar, 2011, Foreign Exchange Intervention: A Shield Against Appreciation Winds?, IMF Working Paper WP/11/165.

Aizenman, J. and K. Lee, 2005. International reserves: precautionary versus mercantilist views, theory and evidence. IMF working Paper № 05/198.

Barr, N., and P. Diamond, 2006. The economics of pensions. Oxford review of economic policy, 22 (1): 15-39.

BIS, 2005. Foreign Exchange Market Intervention in Emerging Markets: Motives, Techniques, and Implications. BIS Paper No. 24.

BIS, 2013. Market volatility and foreign exchange intervention in EMEs: what has changed?. BIS Paper No. 73.

Blinder, A. S., et al., 2008. Central bank communication and monetary policy: A survey of theory and evidence. Journal of Economic Literature, 46 (4): 910-45.

Calvo, G., Leiderman L. and C. Reinhart, 1993. Capital Inflows and Real Exchange Rate Appreciation in Latin America. IMF Staff Papers, 40 (1): 108-151.

Cheng, G., 2016. The Global Financial Safety Net through the Prism of G20 Summits. European Stability Mechanism. Working Papers Series No. 13.

Cordella, T. and E. Levy Yeyati, 2010. Global safety nets: The IMF as a swap clearing house. VoxEU.org.

Cowen, K., Levy Yeyati, E., Panizza, U. and F. Sturzenegger, 2006. Sovereign Debt in the Americas: New Data and Stylized Facts. CIF Working Paper No. 9.

Daude, C., Levy Yeyati, E. and A. Nagengast, 2014. On the effectiveness of exchange rate intervention in emerging markets. OECD Development Centre Working Paper No. 324.

Feldstein, M., 1999. A Self-Help Guide for Emerging Markets. Foreign Affairs, 78 (2): 93-109.

Fernández-Arias, E. and E. Levy Yeyati, 2010. Global Financial Safety Nets: Where Do We Go from Here? IDB Working Paper Series No. 231.

González Rozada, M., and E. Levy Yeyati, 2005. Global Factors and Emerging Market Spreads. IDB Working Paper 552.

Jeanne, O. and R. Ranciere, 2006. The Optimal Level of International Reserves for Emerging Market Countries: Formulas and Applications. IMF Working Paper 06/229.

Jeanne, O., and D. Sandri, 2016. Optimal reserves in financially closed economies. NBER Working Paper No. 22139. 
Jeanne, O., and R. Ranciere, 2011. The Optimal Level of International Reserves for Emerging Market Countries: Formulas and Applications. Economic Journal, 121(555): 905-930.

Levy Yeyati, E. and F. Sturzenegger, 2000. Implications of the Euro for Latin America's Financial and Banking Sectors. Emerging Markets Review, 1(1): 53-81.

Levy Yeyati, E. and F. Sturzenegger, 2005. Classifying Exchange Rate Regimes: Deeds vs. Words. European Economic Review, 49 (6): 1603-1635.

Levy Yeyati, E. and F. Sturzenegger, 2010. Monetary and Exchange Rate Policies and Economic Development, in Rosenzweig, M. and D. Rodrik (eds.), Handbook of Development Economics 5, Chapter 64, Elsevier.

Levy Yeyati, E., 2006a. Liquidity Insurance in Financially Dollarized Economies. NBER Working Paper No 12345.

Levy Yeyati, E., 2006b. Financial Dollarization. Economic Policy 21 (45): 61-118.

Levy Yeyati, E., 2010. What drives reserve accumulation (and at what cost)?. VoxEU.org.

Levy Yeyati, E., 2011. Cost of Reserves. Economics Letters, 100 (2008): 39-42.

Obstfeld, M., Shambaugh J.C. and A.M. Taylor, 2010. Financial stability, the trilemma, and international reserves. American Economic Journal: Macroeconomics, 2 (2): 57-94.

Richhild M. and W.A. Allen, 2010. Options for meeting the demand for international liquidity during financial crisis. BIS Quarterly Review, 51-61.

Rodrick, D., 2006. The Social Cost of Foreign Exchange Reserves. NBER Working Paper No 11952.

Romer, C.D. and D.H. Romer, 2000. Federal Reserve Information and the Behavior of Interest Rates. American Economic Review, 90 (3): 429-457.

Sarno, L. and M. Taylor, 2001. Official intervention in the foreign exchange market: is it effective and, if so, how does it work?. Journal of Economic Literature, 39 (3): 839-868.

Sarno, L. and M. Taylor, 2002. The economics of Exchange Rates, Cambridge, Cambridge University Press. 
Table 1 Summary Statistics of Selected Variables

\begin{tabular}{lccccc} 
Statistic & $N$ & Mean & St. Dev. & Min & Max \\
\hline \hline Sovereign Spread & 3,149 & 337.605 & 213.240 & 21.200 & 998.524 \\
US 10 year yield & 3,149 & 3.669 & 1.339 & 1.500 & 6.660 \\
Risk Aversion & 3,149 & 519.289 & 175.745 & 257 & 1,068 \\
Credit Rating & 3,149 & 17.308 & 2.357 & 8 & 21 \\
Reserves Ratio & 3,149 & 0.157 & 0.082 & 0.012 & 0.409 \\
Sovereign Debt Ratio & 3,149 & 0.199 & 0.111 & 0.009 & 0.590 \\
Private Debt Ratio & 3,149 & 0.111 & 0.106 & -0.001 & 0.624 \\
\hline \hline
\end{tabular}

Sources: See Table A1

Table 2: Countries and Period Covered

\begin{tabular}{lrcc} 
Country & obs & Begins & Ends \\
\hline \hline Bulgaria & 157 & $1998-12-01$ & $2013-12-01$ \\
Brazil & 194 & $1997-12-01$ & $2017-12-01$ \\
Colombia & 217 & $1997-12-01$ & $2017-12-01$ \\
Dominican Republic & 155 & $2001-11-01$ & $2017-12-01$ \\
Egypt Arab Rep. & 174 & $2001-07-01$ & $2017-12-01$ \\
Indonesia & 140 & $2004-05-01$ & $2017-12-01$ \\
Morocco & 164 & $1998-04-01$ & $2017-12-01$ \\
Mexico & 217 & $1997-12-01$ & $2017-12-01$ \\
Nigeria & 97 & $2006-03-01$ & $2017-12-01$ \\
Pakistan & 140 & $2002-02-01$ & $2017-12-01$ \\
Peru & 216 & $1998-01-01$ & $2017-12-01$ \\
Philippines & 217 & $1997-12-01$ & $2017-12-01$ \\
Russian Federation & 183 & $1997-12-01$ & $2017-12-01$ \\
Thailand & 100 & $1997-12-01$ & $2006-03-01$ \\
Tunisia & 83 & $2002-05-01$ & $2011-03-01$ \\
Turkey & 214 & $1997-12-01$ & $2017-12-01$ \\
Ukraine & 153 & $2002-01-01$ & $2017-12-01$ \\
Venezuela RB & 111 & $1997-12-01$ & $2014-07-01$ \\
South Africa & 217 & $1997-12-01$ & $2017-12-01$ \\
\hline \hline
\end{tabular}


Table 3: Elasticities of emerging market spreads to reserves and debt ratios Full Sample

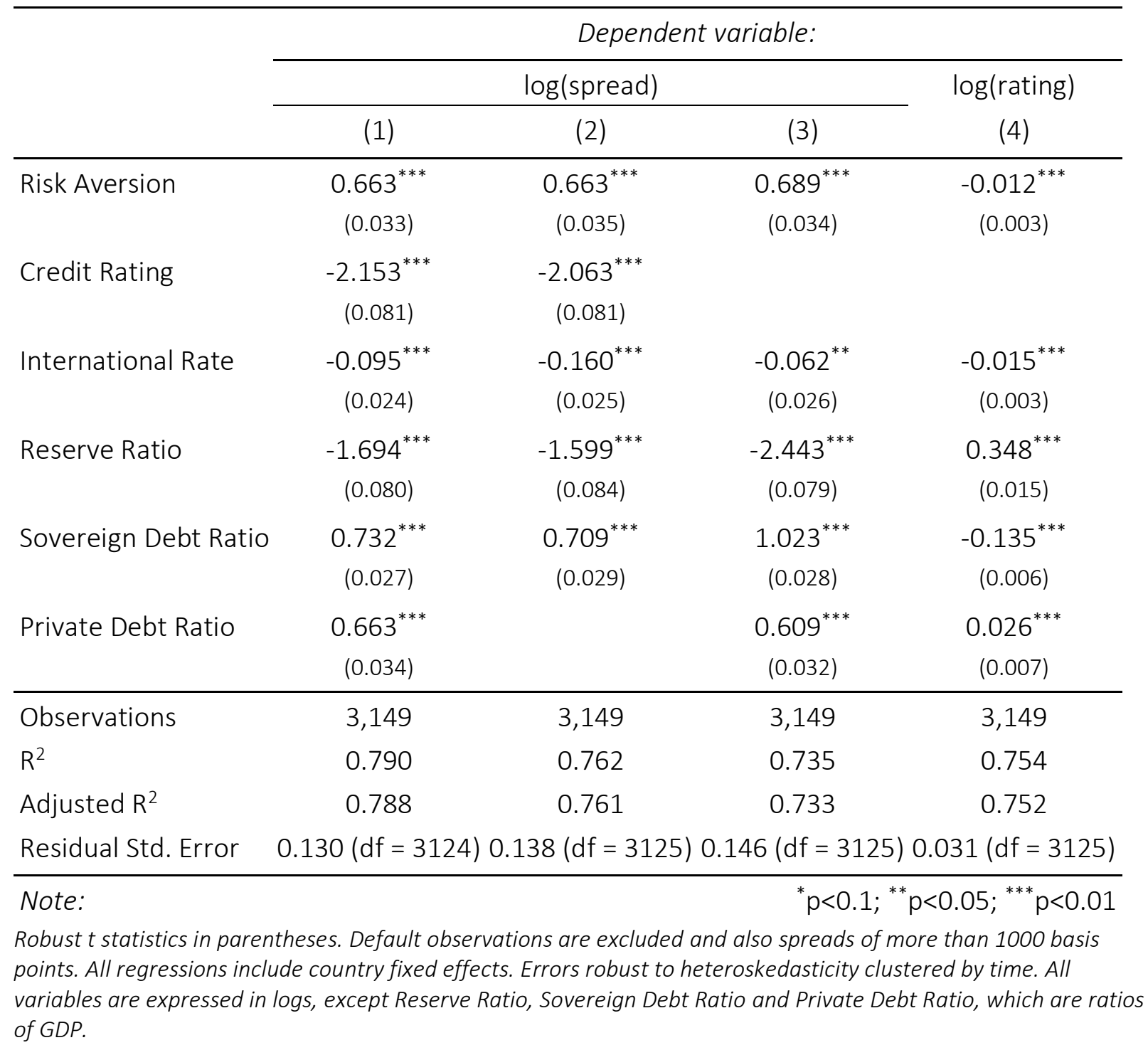


Table 4. Elasticities of emerging market spreads to reserves and debt ratios: Before International Financial Crisis

\begin{tabular}{|c|c|c|c|}
\hline & \multicolumn{3}{|c|}{ Dependent variable: } \\
\hline & \multicolumn{2}{|c|}{$\log ($ spread) } & \multirow{2}{*}{$\begin{array}{c}\log \text { (rating) } \\
\text { (3) }\end{array}$} \\
\hline & (1) & $(2)$ & \\
\hline Risk Aversion & $\begin{array}{c}0.633^{* * *} \\
(0.036)\end{array}$ & $\begin{array}{c}0.664^{* * *} \\
(0.036)\end{array}$ & $\begin{array}{c}-0.017^{* * *} \\
(0.004)\end{array}$ \\
\hline Credit Rating & $\begin{array}{c}-1.901^{* * *} \\
(0.121)\end{array}$ & & \\
\hline International Rate & $\begin{array}{c}0.507^{* * *} \\
(0.075)\end{array}$ & $\begin{array}{c}0.522^{* * *} \\
(0.077)\end{array}$ & $\begin{array}{l}-0.008 \\
(0.007)\end{array}$ \\
\hline Reserve Ratio & $\begin{array}{c}-1.919^{* * *} \\
(0.173)\end{array}$ & $\begin{array}{c}-1.990^{* * *} \\
(0.170)\end{array}$ & $\begin{array}{c}0.038^{* *} \\
(0.019)\end{array}$ \\
\hline Sovereign Debt Ratio & $\begin{array}{c}1.079^{* * *} \\
(0.060)\end{array}$ & $\begin{array}{c}1.554^{* * *} \\
(0.054)\end{array}$ & $\begin{array}{c}-0.249^{* * *} \\
(0.016)\end{array}$ \\
\hline Private Debt Ratio & $\begin{array}{c}0.835^{* * *} \\
(0.071)\end{array}$ & $\begin{array}{c}0.607^{* * *} \\
(0.065)\end{array}$ & $\begin{array}{c}0.120^{* * *} \\
(0.009)\end{array}$ \\
\hline Observations & 1,701 & 1,701 & 1,701 \\
\hline$R^{2}$ & 0.855 & 0.836 & 0.820 \\
\hline Adjusted $\mathrm{R}^{2}$ & 0.852 & 0.833 & 0.818 \\
\hline Residual Std. Error & $0.123(d f=16$ & $31(d f=167$ & $023(d f=1677)$ \\
\hline Note: & & ${ }^{*} p<0$ & $0.05 ;{ }^{* * *} p<0.01$ \\
\hline
\end{tabular}


Table 5. Elasticities of emerging market spreads to reserves and debt ratios: After International Financial Crisis

\begin{tabular}{|c|c|c|c|}
\hline & \multicolumn{3}{|c|}{ Dependent variable: } \\
\hline & \multicolumn{2}{|c|}{$\log ($ spread $)$} & \multirow{2}{*}{$\begin{array}{c}\log \text { (rating) } \\
\text { (3) }\end{array}$} \\
\hline & (1) & $(2)$ & \\
\hline Risk Aversion & $\begin{array}{c}0.420^{* * *} \\
(0.045)\end{array}$ & $\begin{array}{c}0.431^{* * *} \\
(0.041)\end{array}$ & $\begin{array}{c}-0.009^{* *} \\
(0.004)\end{array}$ \\
\hline Credit Rating & $\begin{array}{c}-1.264^{* * *} \\
(0.173)\end{array}$ & & \\
\hline International Rate & $\begin{array}{r}-0.123^{*} \\
(0.066)\end{array}$ & $\begin{array}{l}-0.100 \\
(0.061)\end{array}$ & $\begin{array}{c}-0.019^{* * *} \\
(0.005)\end{array}$ \\
\hline Reserve Ratio & $\begin{array}{c}-0.881^{* * *} \\
(0.142)\end{array}$ & $\begin{array}{c}-1.322^{* * *} \\
(0.160)\end{array}$ & $\begin{array}{c}0.349^{* * *} \\
(0.034)\end{array}$ \\
\hline Sovereign Debt Ratio & $\begin{array}{c}0.987^{* * *} \\
(0.098)\end{array}$ & $\begin{array}{c}1.370^{* * *} \\
(0.072)\end{array}$ & $\begin{array}{c}-0.303^{* * *} \\
(0.017)\end{array}$ \\
\hline Private Debt Ratio & $\begin{array}{l}0.041 \\
(0.134)\end{array}$ & $\begin{array}{l}-0.009 \\
(0.135)\end{array}$ & $\begin{array}{l}0.040^{*} \\
(0.023)\end{array}$ \\
\hline Observations & 1,448 & 1,448 & 1,448 \\
\hline$R^{2}$ & 0.803 & 0.787 & 0.892 \\
\hline Adjusted $\mathrm{R}^{2}$ & 0.800 & 0.784 & 0.890 \\
\hline Residual Std. Error & $0.101(d f=1424)$ & $0.105(d f=1425)$ & $0.023(d f=1425)$ \\
\hline
\end{tabular}

Robust $t$ statistics in parentheses. Default observations are excluded and also spreads of more than 1000 basis points. All regressions include country fixed effects. Errors robust to heteroskedasticity clustered by time. All variables are expressed in logs, except Reserve Ratio, Sovereign Debt Ratio and Private Debt Ratio, which are ratios of GDP. 
Table A1: Variable definitions and sources

\begin{tabular}{|c|c|c|}
\hline Name & Description & Source \\
\hline Sovereign Spread & $\begin{array}{l}\text { JP Morgan EMBI global index blended } \\
\text { spread, in bps }\end{array}$ & The World Bank \\
\hline Risk aversion & Merrill Lynch High Yield Master II, in bps & $\begin{array}{l}\text { Federal Reserve Bank of St. } \\
\text { Louis }\end{array}$ \\
\hline International Rate & $\begin{array}{l}\text { US Treasury notes, } 10 \text { year constant } \\
\text { maturity yield, bps }\end{array}$ & $\begin{array}{l}\text { Federal Reserve Bank of St. } \\
\text { Louis }\end{array}$ \\
\hline Credit rating & $\begin{array}{l}\text { S\&P rating, long term debt, end of period, } \\
\text { foreign currency. We construct an index } \\
\text { starting in } 1 \text { at "Not Rated (NR)" up to the } \\
\text { top in } 30 \text { at "AAA". }\end{array}$ & Standard \& Poor's \\
\hline Reserves & Total international reserves & $\begin{array}{l}\text { IMF's International } \\
\text { Financial Statistics (IFS) }\end{array}$ \\
\hline Sovereign Debt & $\begin{array}{l}\text { Public and publicly guaranteed debt from } \\
\text { private creditors }\end{array}$ & $\begin{array}{lr}\text { The World } & \text { Bank's, } \\
\text { International } & \text { Debt } \\
\text { Statistics (IDS) } & \end{array}$ \\
\hline Private Debt & $\begin{array}{l}\text { External debt stock }<\text { s, private } \\
\text { nonguaranteed }\end{array}$ & $\begin{array}{l}\text { The World } \\
\text { International } \\
\text { Statistics (IDS) }\end{array}$ \\
\hline GDP & GDP, current US dollars & The World Bank \\
\hline
\end{tabular}

